\title{
Sensory properties of Satsuma mandarin by quantitative descriptive analysis
}

\author{
Kyung Hyung $\mathrm{Ku}^{*}$, Kyung-A Lee, Jeong Hee Choi \\ Research Group of Food Storage and Distribution, Korea Food Research Institute, Seongnam 463-746, Korea
}

\section{감귤의 묘사적 관능 특성}

\author{
구경형* · 이경아 · 최정희 \\ 한국식품연구원 저장유통연구단
}

\begin{abstract}
This study investigated the sensory attributes of Satsuma mandarins to provide basic data for the establishment of a quality grade establishment of mandarins. Samples of the mandarins in different sizes (small, medium, and large) were collected via organic green house cultivation, conventional cultivation without pesticides and conventional cultivation in Jeju Island. Eight trained panels performed the triplicate measurements. From the results of the quantitative descriptive analysis, mandarin samples were selected with five types of appearances (gloss intensity, color intensity, peel width, damage degree, and peel texture), three types of odors (sour, sweet, fresh), six types of tastes (sour, sweet, bitter, fresh, tasteless, and off flavor) four types of texture (hardness, granule toughness, juicy, and tough feel), and three types of after-tastes (sour, sweet, and bitter). The results of the analysis of the quality characteristics of the samples showed that their, $\mathrm{pH}$, total acidity and solids contents differed depending on the size of the samples more than their cultivation methods. The correlation coefficients between the quality properties of the mandarins showed that their, sample size was positively correlated with their peel width and toughness. Moreover, the soluble solid of sample was positively correlated with its color intensity, sweet and fresh orange flavor. However, soluble solid content of the samples was negatively coreelated with their bitter flavor, tastelessness, and off flavor. In the principal component analysis of the sensory attributes data, PC1 represented the soluble solid, gross intensity, orange color, sour and sweet odor, unique mandarin flavor (sweet and, fresh orange), etc., and PC2 (26.77\%) the size, pH, sample acidity, and peel texture.
\end{abstract}

Key words : mandarin, sensory properties, quantitative descriptive analysis, cultivation method

\section{서 론}

감귤류(Citrus unshiu $\mathrm{M}$ 또는 Citrus mandarin)는 운향목 운향과에 속하는 감귤나무아과 식물로 원시 식물은 중국 중남부, 인도차이나 반도에 걸친 아시아 대륙의 동남부 주 변에 분포하고 있다 $(1,2)$. 국내에서 감귤이 가장 많이 생산

*Corresponding author. E-mail : khku@kfri.re.kr Phone : 82-31-780-9052, Fax : 82-31-709-9876

Received 5 August 2014; Revised 3 September 2014; Accepted 3 September 2014.

Copyright (c) The Korean Society of Food Preservation. All rights reserved.
되는 곳은 제주로 2011 년 기준으로 재배면적 $20,747 \mathrm{ha}$, 생산량 668,484 톤에 이르며 감귤 재배 면적중 $86.4 \%$ 가 노지 에서 생산되는 온주 밀감(Citrus unshiu)이고, 이중 97.3\%가 11 월 중순부터 수확하는 조생 온주 밀감이 차지하고 있다 (3). 최근 소비자들은 재배 친환경 농산물에 대한 선호도가 증가되고 있어 과일류도 노지 관행 재배 대비 유기농과 무농약 재배가 증가하는 추세이고, 2016년 저농약 인증제 도 폐지가 되면 유기농와 무농약 재배 등의 친환경 농산물 시장 규모가 확대될 것이라고 전망하고 있다(4). 현재 제주 도 감귤의 친환경 감귤 재배 면적은 최근 몇 년간 1,500 $\mathrm{ha}$ 로 전체 재배 면적의 $7 \%$ 로 추정하고 있다.

감귤에 관한 연구 논문으로는 온주 밀감의 품질 규격화 
를 위한 특성 평가(5), 재배지역, 수확시기, 재배 방법에 따른 온주 밀감의 특성 평가(6-9), 조생감귤의 품질 특성 연구(10), 전처리 조건에 따른 감귤류의 특성 연구(11-12) 등이 있다. 이외에 국조생 온주 밀감의 품질 개선으로 개발 된 '상도조생' 온주밀감의 특성 연구(13), 감귤류의 산업적 활용을 위한 연구와 감귤의 생리 활성 연구(14-17) 등 다양 한 분야의 연구가 보고되었는데, 주로 국내에서 많이 생산 되는 노지 재배 온주 밀감에 관한 것이다. 또 최근에는 과일 의 품질에 따라 등급별 적절 가격을 얻을 수 있고 농가 소득과 직결되므로 생산자는 양질의 과일 생산을 유도하고 있다. 이에 소비자가 신뢰성 있는 등급화된 과일을 제공하 기 위하여 소비자 선호도 조사에 의한 객관적인 품질과 품질 등급 기준 설정, 소비 실태와 감귤의 선호도 분석 (18-20) 등에 대한 논문도 보고되고 있다.

이와 같이 과일의 소비 행태 분석과 객관적인 품질 등급 기준에 관한 연구 등이 진행되고 있으나, 소비자의 객관적 인 기호도를 반영한 품질 등급 기준에 관한 연구는 시작 단계에 있고 특히 소비자의 품질 지표와 관련된 관능적 특성 연구는 거의 없는 실정이다.

본 연구는 제주 감귤의 정량적 묘사 특성에 의한 관능 특성 개발과 친환경 재배인 유기농 하우스 감귤과 무농약 노지 감귤 및 관행 재배 감귤의 관능적 특성 분석과 이화학 적인 품질 지표와의 상관관계를 분석하여 친환경 재배 감귤 의 품질 등급 기준 설정을 위한 기초 자료로 이용하고자 수행되었다.

\section{재료 및 방법}

\section{시 료}

본 실험에 사용된 감귤은 제주 서귀포에 위치한 농가에 서 조생종 온주 감귤(Citrus unshiu)을 2013년 12월 중순 적숙기에 수확하여 선과 과정을 거치지 않고 $10 \mathrm{~kg}$ 단위로 포장한 온주 감귤을 총 $80 \mathrm{~kg}$ 을 제공받아 $1^{\circ} \mathrm{C}$ 저장고에서 유지하면서 실험에 사용하였다. 감귤시료는 동일 농가에서 동일 품종으로 하우스에서 유기농으로 재배한 시료(OCIG) 와, 노지에서 무농약으로 재배한 시료(CCWP)였고 관행재 배 감귤(CC)은 2013년 12월에 수확된 감귤을 서울 가락동 시장 공판장에서 구매하여 사용하였다. 하우스 재배 감귤 은 재배지에 간이 구조물을 설치하고 천정과 북서쪽 옆창 부분을 투명한 폴리에틸렌 필름으로 피복하고, 다른 옆창 은 방풍망으로 피복하여 빗방울이 작물에 직접 닿지 않도록 하여 재배된 시료와 노지 재배는 구조물 설치없이 재배된 시료였다. 이화학적 특성과 관능적 품질 특성 분석을 위해 제공 받은 각 시료군마다 혼합한 후 대 $(150 \mathrm{~mL}$ 이상 $)$, 중 (80 95 mL), 소 $(50 \mathrm{~mL}$ 이하)로 나누고, 개당 윗면과 아랫면 으로 반절을 나누어 윗부분은 이화학적 품질 특성 분석에
사용하고, 아랫면은 관능검사 시료로 이용을 하였다.

\section{크기, 고형분 함량, $\mathrm{pH}$ 및 적정산도}

감귤의 크기는 Volscan Profiler(Stable Micro System Ltd., Vienna Court, UK)로 감귤을 횡으로 감귤 중앙에 움푹 들어 간 부분까지 부피와 무게를 측정하였다. 이때 조건은 감귤 표면에 상처가 나지 않도록 고무핀을 사용하였고, vertical step $15 \mathrm{~mm}$, rotation speed $1.0 \mathrm{rps}$ 이었다. 가용성 고형분 함량(soluble solid content)은 감귤 시료를 blender로 균질화 한 후 거즈로 여과한 추출액을 디지털 당도계(N-1E, Atago, Tokyo, Japan)를 이용하여 각 처리구당 5 회 반복하여 평균 값을 구하였다. $\mathrm{pH}$ 는 감귤 시료를 blender로 균질화한 액을 거즈로 여과하여 얻은 추출액 $3 \mathrm{~mL}$ 와 증류수 $27 \mathrm{~mL}$ 와 섞어 총량이 $30 \mathrm{~mL}$ 되게 한 후 $\mathrm{pH}$ meter(720, Origon, Japan) 를 측정하였다. 적정 산도는 추출액 $3 \mathrm{~mL}$ 와 증류수 $27 \mathrm{~mL}$ 를 혼합하여 $0.1 \mathrm{~N} \mathrm{NaOH}$ 용액으로 $\mathrm{pH}$ 가 8.3이 될 때까지 적정하여 소비된 $0.01 \mathrm{~N} \mathrm{NaOH}$ 용액 소비량을 구한 후 citric acid로 환산하여 표시하였다(21).

\section{관능검사 시료 준비 및 제시}

묘사 용어 개발과 훈련에 사용한 시료는 신선한 온주 감귤, 장기 보관된 온주 감귤, 유기농 하우스 재배 감귤, 무기농 노지 재배 감귤, 관행 재배 감귤 등을 크기별로 한 개씩 제시하였다. 본 실험의 시료 제시는 수평으로 반절한 감귤 시료중 한 부분만을 취하여 불완전블럭법으로 계획하 여 패널 요원에게 평가하도록 하였다.

\section{패널 선발 및 평가}

묘사 용어 도출과 표준 지표 개발을 위한 패널은 원내 게시판을 이용하여 모집을 하였으며, 이때 훈련을 받지 않 은 한국식품연구원에 근무하고 있는 연구원 30명중 맛 차 이에 예민한 패널 요원을 선정하기 위하여 4 가지 기본 맛 (단맛, 짠맛, 신맛, 쓴맛)에 대한 기본 맛 인지 검사 및 순위 검사를 실시하였다. 검사 결과 정답률이 $75 \%$ 이상인 요원 과 지속적으로 본 실험에 참여 의사와 표현 능력 등을 고려 하여 8명을 패널 요원으로 선정하여 실험을 실시하였다 (22). 감귤의 묘사 분석은 훈련과 본 실험으로 나누어서 진행을 하였고, 패널의 훈련 과정은 관능적 특성을 도출하 는 묘사 용어 개발 단계 및 도출된 각각의 묘사 용어의 표준 시료를 확립하는 단계로 나누었으며, 본 실험에서는 3 주간 훈련한 후 확립한 묘사 용어를 이용하여 유기농 하우 스 감귤, 무농약 노지 감귤 및 관행 재배 감귤에 대한 관능적 특성 강도를 15 점 선척도로 평가하였다.

본 실험에서 각 시료의 관능적 특성 강도를 평가할 때에 는 훈련에서 확립한 표준 시료 및 그 강도를 제시하여 각 시료에 대한 정확도를 유도하였으며 관능적 특성 용어 및 표준 시료와 강도 척도는 Table 1 과 같다. 둔화 효과를 제어 
Table 1. Sensory attributes, definitions, and physical standards of Satsuma mandarin.

\begin{tabular}{|c|c|c|c|c|}
\hline & \multirow{2}{*}{ Attributes } & \multirow{2}{*}{ Written definition } & \multicolumn{2}{|c|}{ Standard reference } \\
\hline & & & Low score $(0)$ & High score (15) \\
\hline \multirow{5}{*}{ Appearance } & Gloss intensity & Gross degree of sample peel & Matt & Gloss of color chart \\
\hline & Color intensity & Intensity of Mandarin color & Pastro & 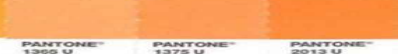 \\
\hline & Width of peel & Width of sample peel & $0.5 \sim 1.5 \mathrm{~mm}$ of peel with & $>3.5 \mathrm{~mm}$ of peel width \\
\hline & Damage degree & Damage degree of sample peel & No damage of peel & $>25 \%$ damage of peel \\
\hline & Texture of peel & Smooth or rough feel degree of sample peel surface & № physical & al standards \\
\hline \multirow{3}{*}{ Odor } & Sour & Sour odor & Distilled water & $10 \%(\mathrm{w} / \mathrm{w})$ citric acid solution \\
\hline & Sweet & The odor associated with fructose syrup & Distilled water & $10 \%(\mathrm{w} / \mathrm{w})$ fructose solution \\
\hline & Fresh orange & Unique smell of fresh sample & Distilled water & Fresh mandarin harvest \\
\hline \multirow{6}{*}{ Taste } & Sour & Fundamental taste of citric acid & Distilled water & $0.2 \%(\mathrm{w} / \mathrm{w})$ citric acid solution \\
\hline & Sweet & Fundamental taste of which fructose is typical & Distilled water & $5 \%(w / w)$ fructose solution \\
\hline & bitter & Fundamental taste of which caffeine is typical & Distilled water & $0.05 \%(\mathrm{w} / \mathrm{w})$ caffeine solution \\
\hline & Fresh orange & Unique taste of fresh mandarin without off flavor and taste & Distilled water & Fresh mandarin (within a week after harvest) \\
\hline & Tasteless & Weak taste of typical sample taste & Mixture solution of mandarin juice and water (1:4) & $100 \%$ mandarin juice \\
\hline & Off flavor & Other flavor of typical sample taste & No standards & \\
\hline \multirow{4}{*}{ Texture } & Hardness & Force required to chew sample (fruit) between molar teeth & No standards & \\
\hline & Granule toughness & Force required to chew sample (fruit) granule between molar teeth & No standards & \\
\hline & Juicy & The amount of juice extracted to chew the sample fruit (four times) & No standards & \\
\hline & Tough feel & The amount of pulp left to chew the sample fruit (10 times) & No standards & \\
\hline \multirow{3}{*}{ After taste } & Sour & Fundamental taste of citric acid & Distilled water & $0.2 \%(\mathrm{w} / \mathrm{w})$ citric acid solution \\
\hline & Sweet & Fundamental taste of which fructose is typical & Distilled water & $5 \%(w / w)$ fructose solution \\
\hline & Bitter & Fundamental taste of which caffeine is typical & Distilled water & $0.05 \%(\mathrm{w} / \mathrm{w})$ caffeine solution \\
\hline
\end{tabular}

하기 위해 한 회의 세션당 평가 시료는 4종으로 한정하였다.

각 특성의 평가는 외관, 냄새, 맛, 조직감, 후미 순으로수 행되었으며, 외관의 경우 밀감 표면의 윤기 강도, 오렌지 색 강도, 겉 껍질의 두께, 껍질의 손상 정도, 표면의 부드럽 거나 거친 정도를 평가하였다. 색 강도는 패널 요원간의 토의를 통하여 밀감 표면 색 평가 시 1점에 해당하는 점은 color guide(Pantone solid chips uncoated)에서 $143 \mathrm{U}, 15$ 점에 해당하는 시료는 2013 U로 색이 진해질수록 높은 점수로 평가하게 하였다. 시료의 냄새는 세게 들이마셔 냄새를 맡 은 후 평가하게 하였고, 맛은 밀감 표면 껍질을 벗긴 후 과육을 먹었을 때의 맛을 평가하였으며, 한 시료를 평가한 후에는 약 30 초간의 휴식 시간을 취하게 하였다. 사용한 척도는 15 점 선척도로 사용하였으며, 1 점은 해당 특성이 없다는 것을 나타내고 점수가 높아질수록 특성 강도가 강해 지는 것으로 평가하게 하였다.

\section{통계분석}

유기농 하우스 감귤, 무농약 노지 감귤 및 관행 재배 감귤 의 이화학적 및 관능적 품질 차이를 파악하기 위해 $\operatorname{SAS}(7.2$, SAS Institute, Cary, NC, USA)을 사용하여 분산분석 (analysis of variance)을 수행하였으며 Duncan's multiple range test를 통해 각 시료간의 유의적 차이를 검정하였다.

또 각 시료의 품질과 관능적 특성간의 관계를 요약하여 나타내기 위해서 XLSTAT(Addinsoft, NY, USA)를 이용하 여 요인간의 상관분석(correlation analysis), 주성분 분석 (principle component analysis) 및 계층적 군집분석 (hierachical cluster analysis)을 실시하였다.

\section{결과 및 고찰}

\section{묘사 분석을 통한 감귤의 관능적 특성}

감귤의 묘사 훈련과정에서 패널의 동의하에 결정된 평가 특성은 총 21 개가 도출되었다(Table 1). 도출된 특성들은 외관 특성(5개)으로 감귤 껍질의 광택 강도, 오렌지 색 강도, 껍질의 두께, 껍질 손상정도와 껍질 표면의 거친 정도였고, 향 특성(3개)은 신내, 단내, 신선한 오렌지 냄새였다. 맛 특성(6개)은 신맛, 단맛, 쓴맛, 신선한 감귤 맛, 밍밍한 맛, 이미가 도출되었고, 텍스쳐 특성(4개)은 감귤을 씹었을 때 의 단단한 정도, 과육 알갱이의 단단한 정도, 다즙성 및 
감귤을 씹었을 때 남는 속과피의 양이 도출되었다. 또 후미 (3개)로 신맛, 단맛과 쓴맛 특성이 개발되었고, 각각의 특성 용어의 정의와 개념을 쉽게 인지시키기 위해 결정된 표준 물질은 Table 1에 나타나 있다. 이 결과는 감귤로 만든 스페 인산 가공 쥬스 7종을 대상으로 외관 2종, 향 12 종, 맛 19종, 조직감 1종을 도출한 Carbonell 등(23) 보다 작은 특성이었 다. 또 Plotto 등(24)의 오렌지 쥬스를 대상으로 관능적 특성 을 평가한 결과 향미 6종, 맛과 조직감을 7종으로 도출한 연구과 비교하여 관능특성 항목에 차이가 있었다. 또 사과 에서 4 개의 외관 특성과 5 개 향 특성, 6 개의 조직감 특성 및 5 개의 맛 특성 등 총 20 개의 관능적 용어를 도출한 Seppa 등(25)과 원료 포도에서 5 개 외관 특성, 3 개의 향 특성, 11 개 의 조직감과 맛 특성 등 총 19 개를 도출한 Baiano 등(26)과 비교하여 본 연구에서 감귤의 관능적 용어는 비슷한 수의 용어가 도출되었다. 이와 같이 연구에 사용한 시료가 과일 자체의 특성과 이들 과일을 이용한 가공 제품에 따라 도출 된 용어에 차이가 있었다.

\section{재배 방법별 감귤의 품질 특성}

동일 농가에서 동일 품종으로 유기농 하우스 재배한 시 료와, 노지에서 무농약으로 재배한 시료와 관행재배 감귤 의 이화학적 및 묘사분석을 통한 관능적 품질 특성은 Table 2 와 같다. 재배 방법별 감귤의 부피별로 선별하여 비교 분석 한 결과 대 $(150 \mathrm{~mL}$ 이상)로 분류된 시료군과 중 $(80 \sim 95 \mathrm{~mL})$, 소 $(60 \mathrm{~mL}$ 이하)로 분류된 시료군에 크기별 분류가 된 것을 확인할 수 있었다. 표준 출하규격중 등급 규격에 따라 과실 한 개 무게 기준으로 특대(150 136 g), 대(107 g 이상), 중(75 $\mathrm{g}$ 이상), 소(58 g 이상), 특소(50 g 이하) 등 5 개 등급으로 구분(27)되어 있는데, 본 연구에 사용된 감귤의 경우 대(150 $\mathrm{mL})$ 로 분류한 군은 특대로 구분되고 중 $(80$ 95 mL) 분류군 은 중으로 분류되며, 소 $(60 \mathrm{~mL})$ 분류군은 소로 분류되었다. 가용성 고형분 함량의 경우 유기농 하우스 감귤 $(\mathrm{OCIG})$ 은 $11.08 \pm 0.54 \sim 12.43 \pm 0.65^{\circ} \mathrm{Brix}$, 무농약 관행재배 감귤 (CCWP)은 $13.87 \pm 1.22 ~ 15.07 \pm 2.01^{\circ} \mathrm{Brix}$, 관행 재배(CC)는 $14.91 \pm 0.79^{\circ} \mathrm{Brix}$ 로 유기농 하우스 감귤의 고형분 함량이 가장 낮았고, 크기별로 비교하면 큰 감귤이 작은 감귤 보다 고형분 함량이 적었다. 농산물 표준 출하 규격에 따르면 감귤의 당도 기준(고형분 함량)은 특급에 해당하는 경우 시설 재배 시료는 $12^{\circ} \mathrm{Brix}$, 노지 재배시료는 $10^{\circ} \mathrm{Brix}$, 이상, 상급은 시설 재배인 경우 $11^{\circ} \mathrm{Brix}$ 이상, 노지 재배인 것은 $9^{\circ} \mathrm{Brix}$ 이상으로 규정(27)하고 있는데, 본 연구에 사용한 시료의 경우 $11 \mathrm{oBrix}$ 이상으로 품질 규격 범위에 있었다. $\mathrm{pH}$ 와 산 함량의 경우 무농약 관행 재배 감귤(CCWP)가 $4.2 \pm 0.13 \sim 4.32 \pm 0.20,0.51 \pm 0.09 \sim 0.55 \pm 0.99 \%$, 유기농 하우 스 감귤(OCIG)은 $3.8 \pm 0.18 \sim 4.31 \pm 0.08,0.52 \pm 0.07 \sim 0.64 \pm$ $0.15 \%$ 로 유기농 하우스 감귤 시료가 전반적으로 낮은 $\mathrm{pH}$ 와 약간 높은 산 함량을 가지고 있었다. Hong 등(9)의 온주
밀감의 3 년간 적정산도의 평균 분포를 조사한 결과 0.4 0.8\% 범위에 속하는 과실 비율이 $73.39 \%$ 였고, 생산 년도에 따라 적정 산도와 $\mathrm{pH}$ 가 차이가 있다고 보고하였는 데 본 연구에 사용한 감귤의 경우 그 범위에 속하였다. 또 Ko 등(19)의 감귤의 소비자 선호도 조사를 통한 품질 등급 기준 연구 보고에서 제주 지역의 감귤 브랜드별로 품질 기준을 당도(Brix) 11 12이상, 산도 $1 \%$ 미만, 당산비 평균 14.8 이상으로 정하였는데, 본 연구에 사용한 유기농 온실 재배와 무농약 감귤 시료의 $\mathrm{pH}$ 와 적정 산도도 그 범위에 속하고 당산비의 경우 노지 재배 감귤 당산비 10 에 비해 시설재배 감귤의 당산비가 15 16으로 보고(6)와 비교하여 높은 당산비를 보였다. 이는 신선 과일류의 숙성 및 품질 지표로 사용되는 당산비율은 11 월 초순 이후 감귤의 크기 변화는 없으나 가용성 고형분 함량과 총당이 12 월 초순까 지 계속 증가한다는 보고(28)와 비교하여 유사한 경향을 보였다.

한편 동일한 농장에서 동일한 품종으로 유기농 하우스 재배, 무농약 노지 재배 및 관행 재배한 제주산 감귤의 묘사 분석에 의한 관능특성을 비교하였다(Table 2). 외관의 감귤 껍질의 광택 강도의 경우 유기농 하우스 재배 귤(OCIG)은 6.18 $\pm 2.84 \sim 7.37 \pm 2.85$, 무농약 관행재배 시료(CCWP)는 $7.37 \pm 2.85 \sim 8.01 \pm 2.96$, 관행 재배(CC) 감귤은 $8.62 \pm 2.33$ 으 로 크기에 상관없이 유기농 하우스 재배 시료(OCIG)가 관 행 재배 감귤에 광택도가 낮다고 평가하였다. 강도는 무농 약 관행 재배 시료 $(\mathrm{CCWP})$ 와 관행 재배 시료 $(\mathrm{CC})$ 가 각각 $8.85 \pm 2.09 \sim 9.47 \pm 2.46,8.46 \pm 2.39$ 의 점수로 평가하여 유기농 하우스 재배 시료는 4.61 $\pm 2.12 ~ 5.96 \pm 2.38$ 보다 높은 점수로 평가하였다. 이는 하우스재배 감귤은 과육이 성숙 과정에 서도 과피내의 클로로필 분해와 카로티노이드 색소의 생성 이 완만하여 과피 색이 진하게 되지 않아 노지 재배 감귤에 비해 과피의 색도가 낮은 것으로 판단된다(5). 과피 두께는 유기농 하우스 재배 시료(OCIG)는 5.93 $\pm 2.43 \sim 8.50 \pm 2.80$, 무농약 관행재배 시료(CCWP)는 4.66 $\pm 3.14 ~ 10.34 \pm 2.78$, 관 행재배 시료(CC-M) $5.80 \pm 1.87$ 로 평가하였다. 이는 $\mathrm{Oh}$ 등 (5)의 노지 재배 감귤 과피보다 하우스 재배 감귤의 과피가 더 얇다고 보고한 결과와 달리 비슷한 크기의 감귤을 비교 하였을 때 재배 방법에 따라서는 차이가 없었으나, 감귤 크기에 따른 과피 두께가 다르다고 평가하였다. 감귤 껍질 의 손상 정도는 유기농 하우스 재배시료(OCIG)는 $1.70 \pm$ 1.01 2.25 \pm 2.01 로 거의 손상이 없다고 평가한 반면 무농약 관행재배시료(CCWP)는 $5.51 \pm 3.32 \sim 6.94 \pm 4.09$ 로 표면 손상 이 있다고 평가하였다. 또 껍질 표면의 거친 정도는 감귤 크기에 상관없이 무농약 관행 재배(CCWP)가 유기농 하우 스 재배시료(OCIG) 보다 표면이 거칠다고 평가하였다.

감귤 향중 신향의 경우 유기농 하우스 재배시료(OCIG) 가 무농약 관행재배 시료(CCWP)에 비해 약간 낮은 점수로 평가하였고, 가장 높은 값은 관행 재배 $(\mathrm{CC})$ 였다. 단향의 
Table 2. Quality properties and sensory evaluation of Satsuma mandarin.

\begin{tabular}{|c|c|c|c|c|c|c|c|c|}
\hline \multirow{2}{*}{ Sample } & Cultivation method ${ }^{1)}$ & OCIG & CCWP & OCIG & CCWP & OCIG & CCWP & Control \\
\hline & Size & Small & Small & Medium & Medium & Large & Large & Midium \\
\hline \multirow{5}{*}{ Quality properties } & Size & $\begin{array}{c}59.44 \pm 6.50^{(2)} \\
(66.17 \pm 14.45)\end{array}$ & $\begin{array}{c}49.96 \pm 6.00^{f} \\
(52.50 \pm 10.84)\end{array}$ & $\begin{array}{c}95.87 \pm 13.02^{c} \\
(98.00 \pm 10.62)\end{array}$ & $\begin{array}{c}82.07 \pm 8.79^{\text {cd }} \\
(89.08 \pm 10.76)\end{array}$ & $\begin{array}{l}158.67 \pm 20.05^{\mathrm{ab}} \\
(149.33 \pm 16.24)\end{array}$ & $\begin{array}{c}191 \pm 25.99^{\mathrm{a}} \\
(168.50 \pm 19.11)\end{array}$ & $\begin{array}{l}80.38 \pm 5.43^{\text {cd }} \\
(79.86 \pm 6.32)\end{array}$ \\
\hline & Soluble solid & $12.31 \pm 0.98^{c}$ & $15.07 \pm 2.01^{\mathrm{a}}$ & $12.43 \pm 0.65^{\mathrm{c}}$ & $14.22 \pm 1.19^{\mathrm{ab}}$ & $11.08 \pm 0.54^{d}$ & $13.87 \pm 1.22^{b}$ & $14.91 \pm 0.79^{\mathrm{a}}$ \\
\hline & $\mathrm{pH}$ & $3.8 \pm 0.18^{\mathrm{c}}$ & $4.2 \pm 0.13^{\mathrm{ab}}$ & $4.14 \pm 0.08^{b}$ & $4.27 \pm 0.13^{\mathrm{a}}$ & $4.31 \pm 0.08^{\mathrm{a}}$ & $4.32 \pm 0.20^{\mathrm{a}}$ & $4.06 \pm 0.18^{b}$ \\
\hline & Acidity & $0.64 \pm 0.15^{\mathrm{a}}$ & $0.55 \pm 0.09^{\mathrm{ab}}$ & $0.52 \pm 0.07^{\mathrm{b}}$ & $0.51 \pm 0.09^{b}$ & $0.46 \pm 0.08^{b}$ & $0.54 \pm 0.19^{b}$ & $0.56 \pm 0.12^{\mathrm{ab}}$ \\
\hline & SS/acidity & $26.84 \pm 0.36^{\mathrm{bc}}$ & $25.76 \pm 0.47^{\mathrm{a}}$ & $27.64 \pm 0.16^{c}$ & $27.23 \pm 0.32^{\mathrm{b}}$ & $23.96 \pm 0.14^{\mathrm{d}}$ & $24.10 \pm 0.34^{b}$ & $19.25 \pm 0.26^{\mathrm{a}}$ \\
\hline \multicolumn{9}{|l|}{ Sensory attribute } \\
\hline \multirow{5}{*}{ Appearance } & Gloss intensity & $6.18 \pm 2.84^{\mathrm{b}}$ & $8.01 \pm 2.96^{\mathrm{a}}$ & $6.91 \pm 2.74^{b}$ & $7.87 \pm 2.93^{\mathrm{ab}}$ & $7.37 \pm 2.85^{b}$ & $7.84 \pm 2.39^{\mathrm{ab}}$ & $8.62 \pm 2.33^{\mathrm{a}}$ \\
\hline & Color intensity & $4.71 \pm 2.12^{b}$ & $9.47 \pm 2.46^{\mathrm{a}}$ & $4.94 \pm 1.98^{\mathrm{b}}$ & $9.22 \pm 2.18^{\mathrm{a}}$ & $5.96 \pm 2.38^{c}$ & $8.85 \pm 2.09^{\mathrm{a}}$ & $8.46 \pm 2.39^{\mathrm{a}}$ \\
\hline & Peel width & $5.93 \pm 2.43^{b c}$ & $4.66 \pm 3.14^{\mathrm{c}}$ & $8.10 \pm 2.63^{b}$ & $6.45 \pm 3.49^{c}$ & $8.50 \pm 2.80^{b}$ & $10.34 \pm 2.78^{\mathrm{a}}$ & $5.80 \pm 1.87^{\mathrm{c}}$ \\
\hline & Damage degree & $1.70 \pm 1.01^{\mathrm{b}}$ & $6.94 \pm 4.09^{\mathrm{a}}$ & $1.91 \pm 1.89^{\mathrm{b}}$ & $6.35 \pm 3.11^{\mathrm{a}}$ & $2.25 \pm 2.01^{\mathrm{b}}$ & $5.51 \pm 3.32^{\mathrm{a}}$ & $1.93 \pm 1.78^{\mathrm{b}}$ \\
\hline & Texture of peel & $3.01 \pm 2.07^{\mathrm{b}}$ & $6.58 \pm 3.57^{\mathrm{a}}$ & $3.66 \pm 2.63^{\mathrm{b}}$ & $7.15 \pm 2.73^{\mathrm{a}}$ & $4.32 \pm 2.39^{\mathrm{b}}$ & $7.38 \pm 3.23^{\mathrm{a}}$ & $3.65 \pm 1.74^{b}$ \\
\hline \multirow{3}{*}{ Odor } & Sour & $5.36 \pm 3.55^{\mathrm{b}}$ & $6.33 \pm 4.01^{\mathrm{a}}$ & $5.93 \pm 3.06^{b}$ & $6.97 \pm 3.49^{\mathrm{a}}$ & $6.21 \pm 3.15^{\mathrm{a}}$ & $6.23 \pm 3.34^{\mathrm{a}}$ & $7.82 \pm 2.50^{\mathrm{a}}$ \\
\hline & Sweet & $6.71 \pm 2.88^{\mathrm{a}}$ & $7.08 \pm 2.92^{\mathrm{a}}$ & $5.63 \pm 2.37^{\mathrm{a}}$ & $7.02 \pm 3.07^{\mathrm{a}}$ & $6.01 \pm 3.18^{\mathrm{a}}$ & $7.46 \pm 3.44^{\mathrm{a}}$ & $6.77 \pm 2.98^{\mathrm{a}}$ \\
\hline & Fresh & $7.19 \pm 2.94^{\mathrm{a}}$ & $6.93 \pm 3.63^{\mathrm{a}}$ & $5.54 \pm 3.14^{\mathrm{b}}$ & $7.73 \pm 3.35^{\mathrm{a}}$ & $7.07 \pm 3.33^{\mathrm{a}}$ & $6.99 \pm 3.11^{\mathrm{a}}$ & $7.75 \pm 3.27^{\mathrm{a}}$ \\
\hline \multirow{6}{*}{ Taste } & Sour & $7.64 \pm 3.31^{\mathrm{a}}$ & $5.78 \pm 3.44^{b}$ & $7.27 \pm 2.95^{\mathrm{a}}$ & $5.83 \pm 2.88^{b}$ & $5.76 \pm 2.98^{b}$ & $6.89 \pm 3.93^{\mathrm{bc}}$ & $8.45 \pm 3.17^{\mathrm{a}}$ \\
\hline & Sweet & $4.92 \pm 2.29^{b}$ & $8.78 \pm 2.68^{\mathrm{a}}$ & $4.79 \pm 2.70^{b}$ & $7.73 \pm 3.52^{\mathrm{a}}$ & $4.76 \pm 3.23^{b}$ & $8.77 \pm 2.82^{\mathrm{a}}$ & $9.17 \pm 2.40^{\mathrm{a}}$ \\
\hline & Bitter & $4.22 \pm 3.35^{\mathrm{a}}$ & $2.81 \pm 2.36^{\mathrm{a}}$ & $3.89 \pm 2.67^{\mathrm{a}}$ & $3.17 \pm 2.65^{\mathrm{a}}$ & $3.58 \pm 3.31^{\mathrm{a}}$ & $2.88 \pm 2.08^{\mathrm{a}}$ & $2.71 \pm 2.51^{\mathrm{a}}$ \\
\hline & Fresh & $4.98 \pm 2.92^{\mathrm{b}}$ & $5.30 \pm 3.28^{b}$ & $4.15 \pm 2.69^{b}$ & $5.63 \pm 3.12^{\mathrm{b}}$ & $3.89 \pm 2.93^{\mathrm{c}}$ & $5.71 \pm 2.74^{b}$ & $7.43 \pm 3.06^{\mathrm{a}}$ \\
\hline & Tasteless & $6.02 \pm 4.03^{\mathrm{a}}$ & $3.59 \pm 2.99^{\mathrm{b}}$ & $5.51 \pm 3.15^{\mathrm{b}}$ & $3.80 \pm 2.70^{c}$ & $7.53 \pm 3.48^{\mathrm{a}}$ & $3.17 \pm 2.78^{b}$ & $1.86 \pm 1.90^{c}$ \\
\hline & Off flavor & $4.00 \pm 3.16^{\mathrm{ab}}$ & $2.89 \pm 2.52^{\mathrm{ab}}$ & $4.52 \pm 3.17^{\mathrm{a}}$ & $2.14 \pm 1.85^{b}$ & $3.62 \pm 2.74^{\mathrm{ab}}$ & $2.39 \pm 1.67^{\mathrm{ab}}$ & $1.86 \pm 1.54^{\mathrm{b}}$ \\
\hline \multirow{4}{*}{ Texture } & Hardness & $7.08 \pm 2.78^{a}$ & $7.35 \pm 3.30^{\mathrm{a}}$ & $6.96 \pm 2.28^{a}$ & $7.45 \pm 2.60^{\mathrm{a}}$ & $7.54 \pm 2.03^{\mathrm{a}}$ & $7.36 \pm 2.82^{\mathrm{a}}$ & $6.84 \pm 3.55^{\mathrm{a}}$ \\
\hline & Toughness of granule & $7.35 \pm 2.23^{\mathrm{a}}$ & $8.01 \pm 3.21^{\mathrm{a}}$ & $7.98 \pm 2.27^{\mathrm{a}}$ & $8.23 \pm 2.48^{\mathrm{a}}$ & $7.68 \pm 2.11^{\mathrm{a}}$ & $7.99 \pm 2.26^{\mathrm{a}}$ & $8.64 \pm 1.90^{\mathrm{a}}$ \\
\hline & Juiciness & $7.29 \pm 2.64^{b}$ & $7.83 \pm 2.55^{b}$ & $8.06 \pm 2.70^{\mathrm{a}}$ & $8.02 \pm 2.32^{\mathrm{a}}$ & $7.50 \pm 2.67^{b}$ & $9.33 \pm 1.62^{\mathrm{a}}$ & $9.13 \pm 1.94^{\mathrm{a}}$ \\
\hline & Tough feel & $4.93 \pm 2.73^{b}$ & $4.66 \pm 3.21^{\mathrm{b}}$ & $6.86 \pm 3.08^{\mathrm{ab}}$ & $6.04 \pm 3.15^{b c}$ & $8.12 \pm 2.66^{\mathrm{a}}$ & $7.75 \pm 4.11^{\mathrm{a}}$ & $4.14 \pm 1.95^{b}$ \\
\hline \multirow{3}{*}{ After taste } & Sour & $6.09 \pm 3.78^{\mathrm{a}}$ & $4.70 \pm 3.45^{\mathrm{ab}}$ & $5.24 \pm 3.08^{\mathrm{ab}}$ & $3.64 \pm 2.66^{\mathrm{bc}}$ & $4.06 \pm 3.25^{b}$ & $4.51 \pm 3.24^{\mathrm{ab}}$ & $6.13 \pm 3.78^{\mathrm{a}}$ \\
\hline & Sweet & $2.95 \pm 1.72^{\mathrm{b}}$ & $6.69 \pm 3.26^{\mathrm{a}}$ & $3.23 \pm 1.98^{b}$ & $5.60 \pm 3.61^{\mathrm{a}}$ & $2.65 \pm 2.09^{b}$ & $6.27 \pm 3.68^{\mathrm{a}}$ & $6.50 \pm 3.03^{\mathrm{a}}$ \\
\hline & Bitter & $4.46 \pm 3.56^{\mathrm{a}}$ & $3.65 \pm 2.83^{\mathrm{a}}$ & $3.61 \pm 2.43^{\mathrm{a}}$ & $3.71 \pm 3.10^{\mathrm{a}}$ & $4.11 \pm 3.27^{\mathrm{a}}$ & $3.83 \pm 2.81^{\mathrm{a}}$ & $3.45 \pm 2.05^{\mathrm{a}}$ \\
\hline
\end{tabular}

${ }^{10}$ OCIG, organic cultivation in greenhouse; CCWP, Conventional cultivation without pesticides; CC, conventional cultivation

${ }^{2)}$ The means \pm SD in each column followed by the same letter do not significantly differ $(\mathrm{p}<0.05)$.

경우 유기농 하우스 재배시료(OCIG)는 5.63 $\pm 2.37 ~ 6.71 \pm$ 2.88 , 무농약 관행재배 시료(CCWP)는 7.02 $\pm 3.07 \sim 7.46$ \pm 3.44 의 점수로 평가하였고, 관행재배 시료 $(\mathrm{CC})$ 는 $6.77 \pm 2.98$ 로 평가하였으나 통계적으로는 차이가 없었다. 감귤 고유의 신선한 향은 유기농 하우스 감귤재배 시료 (OCIG)를 제외하고는 통계적으로 차이가 나지 않았다. 감 귤의 신맛은 관행재배 시료 $(\mathrm{CC})$ 가 $8.45 \pm 3.17$ 로 가장 높게 평가하였고, 유기농 하우스 재배 시료(OCIG) 소형과 중형 이 각각 $7.64 \pm 3.31,7.27 \pm 2.95$ 였고, 대형 $5.76 \pm 2.98$, 무농약 관행 재배 시료(CCWP)는 $5.78 \pm 3.44,5.83 \pm 2.88,6.89 \pm 3.93$ 으로 평가였다. 단맛은 전반적으로 무농약 관행재배 시료 (CCWP)가 유기농 하우스 재배시료(OCIG) 보다 높은 점수
로 평가하였고, 쓴맛에는 시료 간 차이가 없었다. 신선한 감귤맛은 관행 재배 시료(CC)가 $7.43 \pm 3.06$ 으로 가장 높다 고 평가하였고, 나머지 시료는 큰 차이가 없었다. 싱거운 맛과 이미(off flavor)의 경우 전반적으로 유기농 하우스 재 배시료(OCIG)가 관행 재배 시료보다 높은 점수로 평가하 였다. 감귤 과육의 조직감 중 단단한 정도와 과육 알갱이의 단단한 정도는 시료간 차이가 없다고 평가하였고, 다즙성 과 과육을 씹은 후 남는 펄프의 양은 전반적으로 크기가 큰 시료가 더 많다고 평가하였었다. 후미 중 신맛은 유기농 하우스 재배 시료(OCIG)가 관행 재배 시료(CCWP)보다 높 다고 평가하였고, 단맛은 낮다고 평가하였으며 쓴맛에는 시료 간에 차이가 없었다. 
감귤 품질특성간의 상관관계 및 통계분석

재배 방법별 감귤의 품질 특성 및 관능적 묘사 특성의 상관관계를 조사한 결과(Table 2), 감귤의 크기와 감귤 껍질 두께 및 감귤 과육을 씹었을 때 남는 펄프의 양과 $1 \%$ 유의수 준에서 양의 상관관계가 있었다. 이는 과일 크기가 증가함 에 따라 껍질의 두께, $\mathrm{pH}$, 산도, 가용성 고형분 함량과 유의 성을 가지고 있다고 보고(6)와 비교하여 껍질의 두께는 상 관성이 있었으나, 다른 품질 특성과는 유의적인 특성을 보 이지 않았다. 고형분 함량은 당산비, 감귤 과피의 색 강도, 단맛, 신선한 감귤맛, 과육 알갱이의 강도, 단 후미와 $1 \%$ 유의 수준에서 양의 상관관계가 있는 반면 쓴맛, 싱거운 맛, 이미와는 음의 상관관계를 나타냈다. 감귤의 $\mathrm{pH}$ 는 관능 적 특성중 후미 신맛과 $1 \%$ 유의 수준에서 음의 상관관계를 보였고, 산도는 후미의 신맛과 양의 상관관계를 보였으며,
신맛과는 유의적 차이를 보이지 않았다. 반면에 당산비는 단맛, 신선한 오렌지 맛, 후미의 단맛과 $1 \%$ 유의수준에서 양의 상관관계를 밍밍한 맛과 과육을 씹은 후 남는 펄프 함량과는 음의 상관관계를 나타내었다. 관능적 특성 항목 인 껍질 표면의 광택 강도는 색 강도, 신향, 단맛, 후미의 단맛과 양의 상관관계를 보였고, 쓴맛, 싱거운 맛, 이미와는 음의 상관관계를 보였다. 감귤 껍질의 두께는 과육을 씹었 을 때 남는 펄프의 양과 양의 상관관계를 보였고, 신향은 쓴맛과 이미와 음의 상관성을 신선한 감귤맛과 양의 상관성 을 나타내었다. 즉, 본 결과에서는 감귤의 이화학적 품질과 관능적 품질 특성과의 상관분석 결과 소비자가 선호하는 품질로 단맛과 신맛이 조화된 감귤 고유의 맛과 신선함을 기준으로 보았을 때 과일의 크기와 상관성이 있는 관능적 특성 항목은 과피 두께와 씹은 후에 남는 펄프의 양으로

Table 3. Correlation coefficients between the quality properties of the Satsuma mandarins in Cheju

\begin{tabular}{|c|c|c|c|c|c|c|c|c|c|c|c|c|c|c|c|c|c|c|c|c|c|c|c|c|c|c|c|}
\hline \multirow{2}{*}{\multicolumn{2}{|c|}{ Variables }} & \multicolumn{5}{|c|}{ Quality properties } & \multicolumn{5}{|c|}{ Appearance } & \multicolumn{3}{|c|}{ Odor } & \multicolumn{6}{|c|}{ Taste } & \multicolumn{4}{|c|}{ Texture } & \multicolumn{3}{|c|}{ After taste } \\
\hline & & Size & SSC & $\mathrm{pH}$ & Acidity & $\begin{array}{r}\text { SS/ } \\
\text { acidity }\end{array}$ & $\begin{array}{l}\text { Gloss } \\
\text { itrasity }\end{array}$ & $\begin{array}{l}\text { Color } \\
\text { intensity }\end{array}$ & $\begin{array}{l}\text { Peel } \\
\text { width }\end{array}$ & $\begin{array}{l}\text { Damage } \\
\text { degree }\end{array}$ & Texture & Sour & Sweet & Fresh & Sour & Sweet & Bitter & Fresh & Tasteless & $\begin{array}{c}\text { Off } \\
\text { flavor }\end{array}$ & Harthess & $\begin{array}{l}\text { Crande } \\
\text { taghenss }\end{array}$ & Juicy & $\begin{array}{l}\text { Tough } \\
\text { feel }\end{array}$ & Sour & Sweet & Bitter \\
\hline \multirow{5}{*}{$\begin{array}{c}\text { Quality } \\
\text { properties }\end{array}$} & Size & 1.00 & & & & & & & & & & & & & & & & & & & & & & & & & \\
\hline & Soluble solid & -0.29 & 1.00 & & & & & & & & & & & & & & & & & & & & & & & & \\
\hline & $\mathrm{pH}$ & 0.61 & 0.09 & 1.00 & & & & & & & & & & & & & & & & & & & & & & & \\
\hline & Acidity & -0.45 & 0.24 & $-0.87^{\star}$ & 1.00 & & & & & & & & & & & & & & & & & & & & & & \\
\hline & SS/acidity & -0.50 & $0.92^{*}$ & -0.30 & 0.56 & 1.00 & & & & & & & & & & & & & & & & & & & & & \\
\hline \multirow{5}{*}{ Appearance } & Gloss intensity & 0.11 & 0.74 & 0.53 & -0.35 & 0.51 & 1.00 & & & & & & & & & & & & & & & & & & & & \\
\hline & Color intensity & 0.07 & $0.85^{*}$ & 0.53 & -0.17 & 0.61 & $0.86^{*}$ & 1.00 & & & & & & & & & & & & & & & & & & & \\
\hline & Peel width & $0.94^{*}$ & -0.45 & 0.51 & -0.43 & -0.63 & -0.11 & -0.17 & 1.00 & & & & & & & & & & & & & & & & & & \\
\hline & Damage degree & 0.05 & 0.62 & 0.55 & -0.17 & 0.37 & 0.45 & $0.82 *$ & -0.11 & 1.00 & & & & & & & & & & & & & & & & & \\
\hline & Texture & 0.34 & 0.51 & 0.71 & -0.31 & 0.21 & 0.49 & $0.81^{*}$ & 0.19 & $0.95^{*}$ & 1.00 & & & & & & & & & & & & & & & & \\
\hline \multirow{3}{*}{ Odor } & Sour & -0.08 & 0.63 & 0.28 & -0.26 & 0.50 & $0.89 *$ & 0.65 & -0.23 & 0.15 & 0.18 & 1.00 & & & & & & & & & & & & & & & \\
\hline & Sweet & 0.13 & 0.69 & 0.11 & 0.35 & 0.63 & 0.44 & $0.77^{*}$ & -0.11 & 0.69 & 0.69 & 0.25 & 1.00 & & & & & & & & & & & & & & \\
\hline & Fresh & -0.09 & 0.40 & -0.03 & 0.14 & 0.41 & 0.47 & 0.54 & -0.34 & 0.24 & 0.23 & 0.56 & 0.63 & 1.00 & & & & & & & & & & & & & \\
\hline \multirow{6}{*}{ Taste } & Sour & -0.13 & 0.11 & -0.66 & 0.60 & 0.37 & -0.05 & -0.30 & -0.06 & -0.65 & -0.62 & 0.19 & -0.07 & 0.00 & 1.00 & & & & & & & & & & & & \\
\hline & Sweet & 0.04 & $0.93^{*}$ & 0.30 & 0.08 & $0.78^{\star}$ & $0.86^{\star}$ & $0.93^{*}$ & -0.20 & 0.63 & 0.62 & 0.68 & $0.79 *$ & 0.51 & 0.06 & 1.00 & & & & & & & & & & & \\
\hline & Bitter & -0.17 & $-0.81^{*}$ & -0.53 & 0.23 & -0.58 & $0.96^{*}$ & $-0.93^{*}$ & 0.09 & -0.60 & -0.63 & $-0.76^{*}$ & -0.62 & -0.45 & 0.10 & -0.94 & 1.00 & & & & & & & & & & \\
\hline & Fresh & -0.15 & $0.80^{*}$ & -0.14 & 0.35 & $0.83^{\star}$ & 0.70 & 0.63 & -0.32 & 0.16 & 0.15 & $0.77^{*}$ & 0.62 & 0.65 & 0.52 & 0.82 & -0.69 & 1.00 & & & & & & & & & \\
\hline & Tasteless & 0.09 & $-0.94^{*}$ & -0.08 & -0.24 & $-0.87^{*}$ & $-0.76^{*}$ & $-0.77^{\star}$ & 0.23 & -0.43 & -0.42 & -0.71 & -0.66 & -0.39 & -0.35 & -0.93 & $0.81^{\star}$ & $-0.90^{*}$ & 1.00 & & & & & & & & \\
\hline & Off flavor & -0.12 & $-0.76^{*}$ & -0.34 & 0.07 & -0.61 & $0.86^{*}$ & $-0.89 *$ & 0.13 & -0.52 & -0.57 & $-0.81^{*}$ & -0.75 & $-0.78^{*}$ & -0.01 & -0.89 & $0.87^{\star}$ & $-0.83^{*}$ & $0.81^{*}$ & 1.00 & & & & & & & \\
\hline \multirow{4}{*}{ Texture } & Hardhess & 0.40 & -0.18 & 0.67 & -0.54 & -0.43 & 0.05 & 0.31 & 0.27 & 0.60 & 0.66 & -0.19 & 0.26 & 0.21 & $0.91^{\star}$ & -0.01 & -0.13 & -0.42 & 0.33 & -0.13 & 1.00 & & & & & & \\
\hline & Granule toughness & -0.60 & $0.82^{*}$ & -0.19 & 0.27 & 0.86 & 0.62 & 0.62 & -0.73 & 0.29 & 0.14 & 0.75 & 0.44 & 0.62 & 0.23 & 0.68 & -0.57 & $0.82^{*}$ & $-0.76^{\star}$ & -0.70 & -0.32 & 1.00 & & & & & \\
\hline & Juicy & 0.48 & 0.56 & 0.32 & -0.05 & 0.42 & 0.68 & 0.55 & 0.37 & 0.17 & 0.34 & 0.60 & 0.45 & 0.17 & 0.42 & 0.72 & -0.71 & 0.70 & $-0.79^{*}$ & -0.66 & -0.28 & 0.28 & 1.00 & & & & \\
\hline & Tough feel & $0.83^{*}$ & -0.62 & 0.64 & -0.67 & $-0.85 *$ & -0.21 & -0.23 & $0.90^{*}$ & -0.01 & 0.24 & -0.34 & -0.28 & -0.38 & -0.43 & -0.40 & 0.20 & -0.63 & 0.52 & 0.28 & 0.56 & $-0.82^{*}$ & 0.02 & 1.00 & & & \\
\hline \multirow{3}{*}{ After taste } & Sour & -0.39 & 0.07 & $-0.85^{*}$ & $0.76^{*}$ & 0.40 & -0.21 & -0.40 & -0.34 & -0.64 & -0.74 & -0.03 & -0.13 & -0.07 & $0.89{ }^{*}$ & -0.05 & 0.23 & 0.36 & -0.18 & 0.19 & $0.89^{*}$ & 0.21 & 0.10 & -0.61 & 1.00 & & \\
\hline & Sweet & -0.02 & $0.96^{*}$ & 0.30 & 0.08 & $0.80^{*}$ & $0.84^{*}$ & $0.93^{*}$ & -0.23 & 0.68 & 0.65 & 0.65 & $0.77^{*}$ & 0.43 & 0.02 & 0.99 & $-0.92^{*}$ & $0.78^{\star}$ & $-0.93^{*}$ & $-0.85^{\star}$ & -0.01 & 0.69 & 0.69 & -0.41 & -0.08 & 1.00 & \\
\hline & Bitter & 0.16 & -0.64 & -0.10 & 0.09 & -0.59 & $-0.79^{*}$ & -0.47 & 0.24 & 0.04 & 0.04 & $-0.89^{*}$ & -0.08 & -0.22 & -0.46 & -0.63 & 0.67 & $-0.76^{*}$ & 0.75 & 0.59 & 0.54 & -0.69 & -0.67 & 0.45 & 0.30 & -0.61 & 1.00 \\
\hline
\end{tabular}

*significant at $\mathrm{p}=0.01$. 

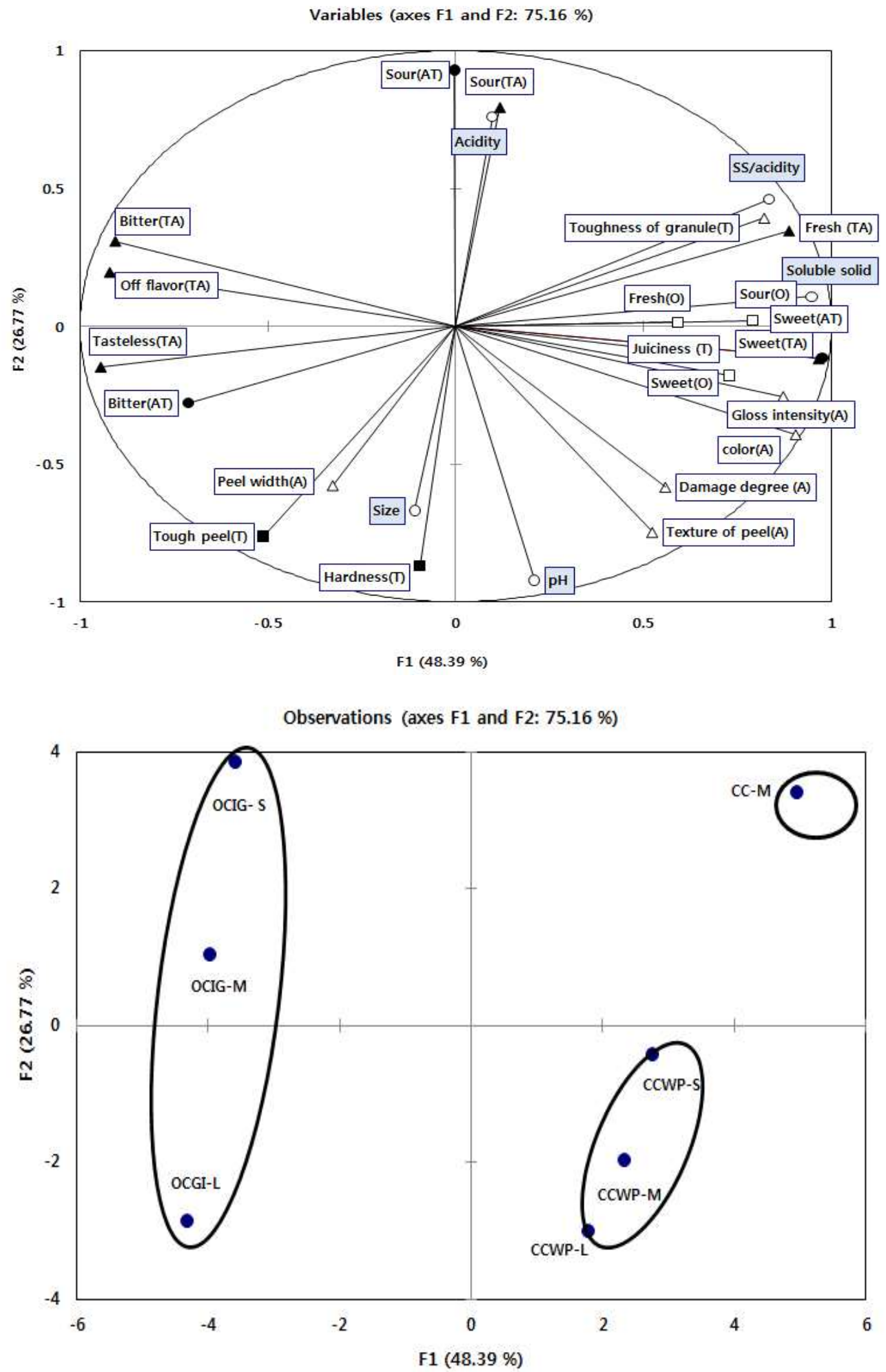

Fig. 1. Analysis of the principal components of the quality properties and sensory attributes of Satsuma mandarins. $(\mathrm{A}, \triangle)$ appearance; (O, $\square$ ), odor; (TA, $\mathbf{\Delta})$, taste; (T, $\square$ ), texture; (AT, $\bigcirc$ ), after taste. OCIG (S,M,L), organic cultivation in greenhouse (size); CCWP (S,M,L), conventional cultivation without pesticides (size); CC, conventional cultivation. 


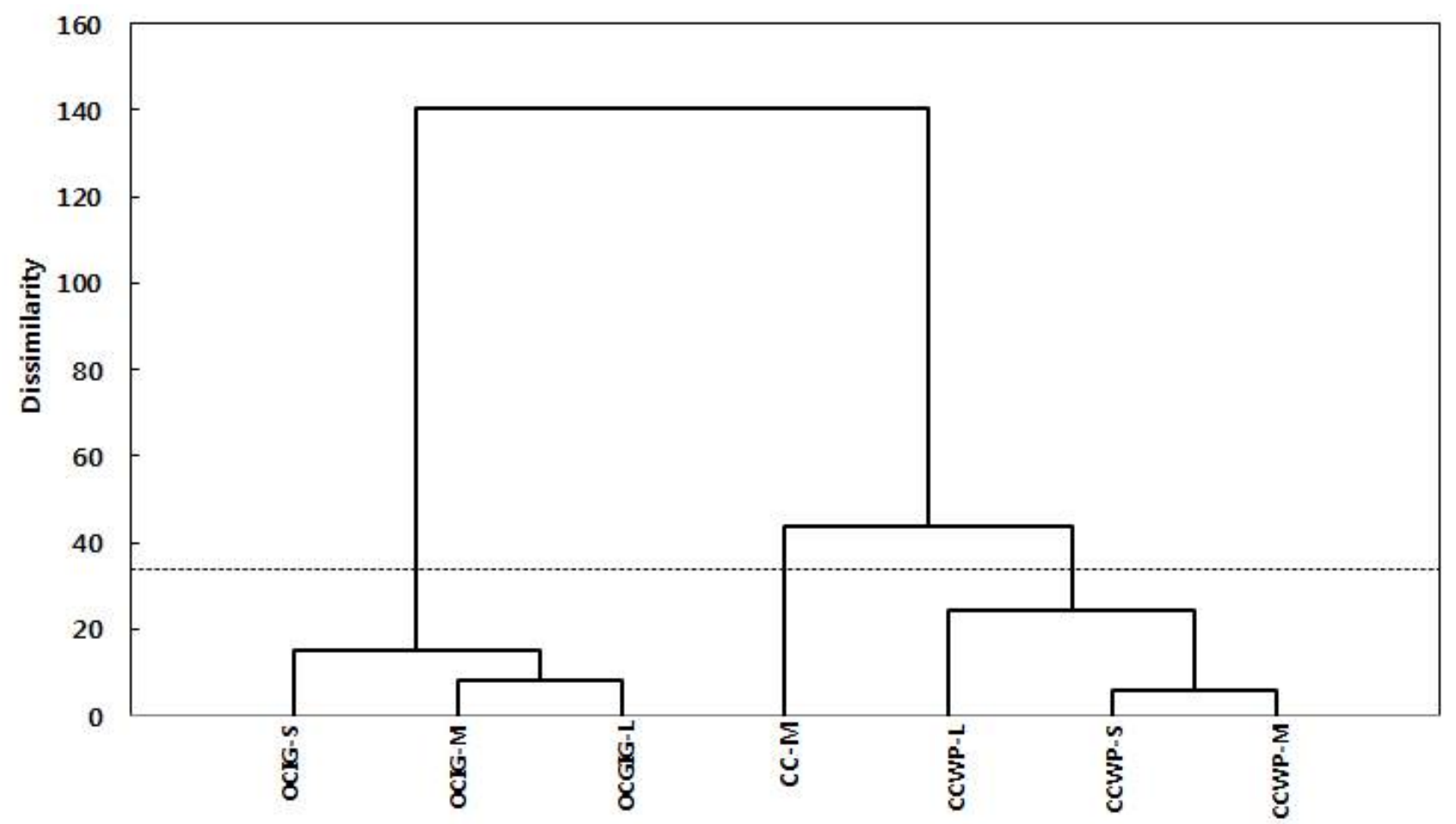

Fig. 2. Dendrogram of Satsma mandarins via. agglomerative hierarchical clustering (AHC) based on the quality properties and sensory attributes of Satsuma mandarin.

OCIG (S,M,L), organic cultivation in greenhouse(size); CCWP (S,M,L), conventional cultivation without pesticides(size); CC-M, conventional cultivation.

분석되었고, 고형분 함량이 많을수록 단맛과 신선한 감귤 맛이 있으며, 후미에 단맛이 많이 남는 것으로 분석되었다. 재배 방법별 감귤의 품질과 관능적 품질 특성의 주성분 분석(principal component analysis) 결과는 Fig. 1과 같다. 첫 번째 주성분(F1)과 두 번째 주성분(F2)는 전체 데이터의 $48.39 \%$ 와 $26.77 \%$ 의 설명력을 보여 주었고, 총설명력은 $75.16 \%$ 였다. 주성분 $\mathrm{F} 1$ 은 가용성 고형분 함량, 당산비, 과 피의 광택 강도, 색 강도, 신향, 단향, 단맛, 쓴맛, 신선한 감귤맛, 싱거운 맛, 이미, 과육 알갱이의 강도, 후미의 단맛 과 쓴맛이었고, $\mathrm{F} 2$ 는 감귤의 크기, $\mathrm{pH}$, 산도, 과피의 손상도, 과피의 조직감, 신맛, 과육의 강도, 과육을 씹었을 때 남는 펄프 함량, 후미의 신맛이었다. 또 주성분 $\mathrm{F} 3$ 는 과피의 두께 와 다즙성이었다. 각 품질 특성의 분포를 보면 $\mathrm{F} 1$ 의 양의 방향으로 당산비, 고형분함량, 신선한 감귤 향과 맛, 단향, 단맛과 후미의 단맛, 과육 알갱이의 단단한 정도, 과피의 광택 강도 색 강도가 분포하였고, 음의 방향으로는 쓴맛과 쓴 후미, 밍밍한 맛, 이미가 분포되었다. 주성분 F2 상으로 는 Y축 양의 방향으로 신맛과 산도, 신 후미가 분포되었고, $\mathrm{Y}$ 축 음의 방향으로는 크기, 과육의 강도, 씹었을 때 남는 펄프의 함량, 껍질의 두께였다. 한편 재배 방법별 감귤의 경우 유기농 하우스 재배 감귤은 $\mathrm{F} 1$ 상의 왼편에 분포하고, 노지 관행재배 감귤은 $\mathrm{F} 1$ 오른쪽에 분포하여 전반적으로
재배 방법별 이화학적 및 관능적 품질 특성에 차이가 있는 것을 알 수 있었다. 한편 Fig. 3 은 재배 방법별 감귤의 품질 특성을 바탕으로 계층적 군집분석(hierarchical cluster analysis based on euclidean distance and ward linkage)한 결과를 덴드로그램으로 나타낸 것이다. 재배 방법별 군집 분석 결과 각 재배방법별 감귤이 각각 분류되었고, 군집간 의 거리를 바탕으로 살펴보면 유기농 하우스 재배 감귤 (OCIS-S, OCIS-M, OCIS-L)이 가까운 거리에 위치하였고, 관행재배 시료(CC)와 무농약 노지 관행재배(CCWP-S, CCWP-M, CCWP-L)이 서로 가까운 위치하였다.

이상의 결과에서 동일 지역의 동일 품종으로 재배된 유 기농 하우스 재배 감귤과 관행 재배 시료와 전반적으로 이화학적 품질 특성과 관능적 특성에 차이가 있다고 구분되 었다. 최근 유기농 재배 감귤에 대한 소비자의 관심도가 급증하고 있고, 실제 소비자가 원하는 감귤의 품질 지표를 알고 유기농 재배와 관행 재배시의 감귤의 차이를 확실히 알아 문제점을 개선하고 생산 농가에서는 고품질 감귤 생산 에 노력이 필요하다고 여겨진다. 본 연구결과는 2013년산 한 지역에서 수집한 감귤만을 시료로 연구가 진행된 것으로 더 많은 유기농 재배 시료와 관행 재배 시료와의 품질 차이 에 대한 연구가 되어야 한다고 여겨진다. 


\section{감사의 글}

본 연구는 농림축산식품부 · 농림수산식품기술기획평 가원 고부가가치식품기술개발사업의 연구비 지원으로 수 행되었으며, 이에 감사드립니다.

\section{요 약}

본 연구는 온주 감귤의 품질 등급 설정을 위한 기초 자료 제공을 위하여 제주 감귤의 묘사적 관능 특성 개발과 재배 방법별 품질 지표간의 상관성을 조사하였다. 제주산 온주 감귤의 훈련된 패널요원에 의해 묘사분석을 한 결과 5 개의 외관 특성(광택 강도, 색 강도, 껍질 두께, 손상 정도, 껍질의 조직감), 3종의 냄새(신내, 단내, 신선한 냄새), 6종의 맛(신 맛, 단맛, 쓴맛, 신선한 맛, 싱거운 맛, 이미), 4종의 텍스쳐 (경도, 알갱이의 경도, 다즙성, 펄프감) 및 3종의 후미(신맛, 단맛, 쓴맛)가 선발되었다. 유기농 하우스재배 및 무농약 노지 재배 감귤과 관행재배 감귤의 품질 특성 중 고형분 함량의 경우 유기농 하우스 감귤의 고형분 함량이 가장 낮았고, 큰 감귤이 작은 감귤보다 고형분 함량이 적었다. 유기농 하우스 재배 귤이 다른 시료에 비해 낮은 $\mathrm{pH}$ 와 약간 높은 산 함량을 가지고 있었다. 감귤의 품질 특성간의 상관 분석결과 감귤 껍질와 과육을 씹은 후 남는 펄프 함량과 음의 상관관계를 보였다. 고형분 함량은 당산비, 감귤 과피 의 색 강도, 단맛, 신선한 감귤맛, 과육 알갱이의 강도, 단 후미와 $1 \%$ 유의 수준에서 양의 상관관계가 있는 반면 쓴맛, 싱거운 맛, 이미와는 음의 상관관계를 나타냈다. 감귤의 이화학적 및 관능적 품질 특성의 주성분 분석 결과 첫 번째 주성분(F1)과 두 번째 주성분(F2)는 전체 데이터의 $48.39 \%$ 와 $26.77 \%$ 의 설명력을 보여 주었고, 총설명력은 $75.16 \%$ 였 다. 주성분 $\mathrm{F} 1$ 은 가용성 고형분함량, 당산비, 과피의 광택 강도, 색 강도, 신향, 단향, 단맛, 쓴맛, 신선한 감귤맛, 싱거 운 맛, 이미, 과육 알갱이의 강도, 후미의 단맛과 쓴맛이었 고, $\mathrm{F} 2$ 는 감귤의 크기, $\mathrm{pH}$, 산도, 과피의 손상도, 과피의 조직감, 신맛, 과육의 강도, 과육을 씹었을 때 남는 펄프 함량, 후미의 신맛이었다. 또 주성분 F3는 과피의 두께와 다즙성이었다. 즉 동일 지역의 동일 품종으로 재배된 유기 농 하우스 재배 감귤과 관행 재배 시료와 전반적으로 이화 학적 품질 특성과 관능적 특성에 차이가 있었다.

\section{References}

1. Yang YH (1994) Citrus fruits illustrated of Cheju. Dea-Young Publishing Co, Korea, p 11-14

2. Scora RW (1975) On the history and origin of citrus. Bull Torrey Botanical Club, 102, 369-375
3. Jeju Special Self-Governing Province (2011) The 2011 State of Agro-Livestock in Jeju. Jeju, Korea, p 97-98

4. Kim CG, Jeong HG, Moon DH (2013) Production status and market outlook of domestic and abroad eco-friendly farm products. Final Report of KREI 2013-55

5. Koh JS, Koh KS, Lim JH (2000) Physicochemical properties and sensory evaluation for grading of Satsuma mandarin produced in Cheju. Korean J Postharvest Sci Technol, 7, 44-50

6. Oh YJ, Hwang IJ, Kim CS, Kang SS, Koh JS (1997) Physicochemical characteristics and sensory evaluation of greenhouse Satusuma mandarin. Agri Chem Bio, 40, 313-317

7. Koh JS, Koh JE, Yang SH, Ahn SU (1994) Physicochemical properties and sensory evaluation of citrus unshiu produced in Cheju. Agr Chem Biotechnol, 37, 161-167

8. Koh JS, Yang YT, Song SC, Kim SH, Kim JY (1997) Cold storage characteristics of early variety of citrus unshiu produced in Cheju with various treatments. Agr Chem Biotechnol, 40, 117-122

9. Koh JS, Song SC (1999) Quality characteristics of Satuma mandarin according to harvest area in Cheju. Korean $\mathbf{J}$ Postharvest Sci Technol, 6, 7-10

10. Hong SI, Lee JW, Kim SH, Jeong MC, Park HW, Kim DM (2003) Quality characteristics and distribution of early harvesting mandarin oranges. Korean J Food Preserv, 10, 54-59

11. Lee HH, Hong SI, Son SM, Kim DM (2004) Storage quality of early harvested Satsuma mandarin as influenced by hot air treatment. Korean J Food Preserv, 11, 304-312

12. Lee GD, Yoon SR (2003) Monitoring of quality properties with drying of citrus. Korean J Food Preserv, 10, 470-475

13. Park YC, Oh HW, Kang JH, Lee JS, Chin SC, Kang SH, Kang SG (2013) Characteristics of new Satsuma mandarin cultivar 'Sangdojosaeng'. Korean J Plant Res, 26, 143-147

14. Kim YD, Ko WJ, Ko KS, Jeon YJ, Kim SH (2009) Composition of flavonoids and antioxidative activity from juice of Jeju native citrus fruits during maturation. Korean J Nutr, 42, 278-290

15. Lee MR, Hwan JH, Oh YS, Oh HJ, Lim SB (2014) Quality characteristics and antioxidant activity of immature citrus unshiu vinegar. J Korean Soc Food Sci Nutr, 43, 250-257 
16. Chung SK, Kim SH, Choi YH, Song EY, Kim SH (2000) Status of citrus fruit production and view of utilization in Cheju. Food Ind Nutr, 5, 42-52

17. Ko SB (2008) An analysis of consumers consumption behavior of environment friendly mandarin and attributes of mandarin in Korea. Korea J Organic Agri, 16, 189-204

18. Ko SB, Hyun CS (2010) Setting the citrus quality standards based on consumer preference survey. Paper presented at 2010 Annual Meeting of J Korea Academia-Industrial cooperation Soc, December 12, Jeju, Korea

19. Ko SB, Hyun CS (2011) Setting in Korean mandarine quality standards based on consumer preference survey. J Korea Academia-Industrial Cooperation Soc, 12, 3430-3438

20. AOAC (1996) Official method of analysis. 15th ed. Association of official analytical chemists. Washington DC, USA, p 607

21. Mailgarrd M, Civille G, Carr B (2007) Descriptive analysis techniques. In : Sensory evaluation techniques, fourth edition. CRC Press. Taylor \& Francis Group, Boca Raton, FL. USA, p 173-186

22. Carbonell L, Izquierdo L, Carbonell I (2007) Sensory analysis of Spanish mandarin juices. Selection of attributes and panel performance. Food Qual Prefer, 18, 329-341

23. Plotto A, Baldwin E, McCollum G, Manthey J, Narciso J, Irey M (2010) Effect of liberibacter infection (Huanglongbing or "Greening" disease) of citrus on orange juice flavor quality by sensory evaluation. J Food Sci, 75, 220-230

24. Seppa L, Railio J, Mononen R, Tahvonen R, Tuorila $\mathrm{H}$ (2012) From profiles to practice : communicating the sensory characteristics of apples to the wider audience through simplified descriptive profiles. LWT-Food Sci Technol, 47, 46-55

25. Baiano A, Terracone C, Peri G, Romaniello R (2012) Application of hyperspectral imaging for prediction of physico-chemical and sensory characteristics of table grapes. Computers and Electronics in Agriculture, 87, $142-151$

26. National agricultural products quality management service (2012) Agricultural standards 2012-84

27. Koh JS, Yang SH, Yang YT, Jwa CS (1998). Physicochemical properties of early cultivar of Satsuma mandarin sampled at different harvested dates in Cheju. Agr Chem Biotechnol, 41, 141-146 